\title{
ESREA: The 7th European Research Conference "Changing configurations of adult education in transitional times"), Berlin 4-7 września 2013 r.
}

Siódma Europejska Konferencja Badawcza zatytułowana „Zmiany konfiguracji nauczania dorosłych w czasach przejściowych", w 2013 roku odbyła się w Uniwersytecie Humbolta w Berlinie. Konferencja organizowana jest przez ESREA (European Society for Research on the Education of Adults) założone w 1991 roku stowarzyszenie naukowe, mające na celu zorganizowanie ogólnoeuropejskiego forum dla badaczy, skupionych wokół tematyki związanej z edukacją osób dorosłych i ich uczeniu się. Głównym priorytetem ESREA jest zachęcanie do kooperacji pomiędzy aktywnymi naukowcami $\mathrm{w}$ formie tematycznych sieci badań, które wspomagają interdyscyplinarne projekty badawcze o szerokim spektrum nauk humanistycznych. Rezultaty prowadzonych badań prezentowane są podczas odbywających się co trzy lata Europejskich Konferencjach Badawczych. Wcześniejsze konferencje miały miejsce między innymi w Strobl (1995), w Brukseli (1998), w Lizbonie (2001), we Wrocławiu (2004), w Sewilli (2007), w Linkoping (2010) i w Berlinie (2013). ESREA wydaje także naukowe czasopismo nazwane RELA. To Europejskie Czasopismo Badań w dziedzinie edukacji i kształcenia dorosłych, jest akademickim czasopismem tworzącym forum do publikacji badań krytycznych na temat edukacji dorosłych i kształcenia ustawicznego. Szczególny nacisk kładzie na kwestie związane z edukacją dorosłych i kształceniem w Europie, które pojawiają się w związku z szerszymi międzynarodowymi i ponadnarodowymi trendami.

$\mathrm{Na}$ temat zmian konfiguracji nauczania dorosłych w czasach przejściowych, dyskutowali podczas konferencji naukowcy z akademickich ośrodków naukowo-badawczych z Szwecji, Finlandii, Szwajcarii, Niemiec, Bułgarii, Portuga- 
lii, Polski, Włoch, Kanady, Luksemburga, Australii, Wielkiej Brytanii, Francji, USA, Słowacji, Chin, Cypru, Estonii, Grecji, Danii Egiptu, Hiszpanii, Holandii, Czech, Ghany, Nowej Zelandii, Austrii, Norwegii, Malty, Serbii, Japonii, Słowenii, Belgii. Ogółem w konferencji uczestniczyło 239 osób. Podczas czterech dni konferencji odbyły się 53 sesje plenarne oraz 6 forum dyskusyjnych.

Polska reprezentowana była przez 8 pracowników naukowych oraz doktorantów z pięciu ośrodków akademickich: z Dolnośląskiej Szkoły Wyższej we Wrocławiu, Uniwersytetu Mikołaja Kopernika w Toruniu, Uniwersytetu Warmińsko-Mazurskiego w Olsztynie, Uniwersytetu Warszawskiego, Uniwersytetu Wrocławskiego.

Tematyka siódmej Europejskiej Konferencji Badawczej „Zmiana konfiguracji nauczania dorosłych w czasach przejściowych" nawiązywała do przeobrażeń zachodzących w edukacji dorosłych i koncepcji nauki przez całe życie, co ma swoje implikacje $\mathrm{w}$ badaniach naukowych. Zaproponowane zagadnienie miało na celu zachęcenie do dyskusji opartej na badaniach dotyczących edukacji dorosłych na poziomie narodowym i europejskim. Istotne w tym kontekście pytania skupiały się na kierunkach rozwoju edukacji dorosłych, naukowym postrzegania tych zmian oraz zyskach i stratach wynikających z zachodzących zmian.

Każdego dnia obrady rozpoczynał wykład, prowadzony przez profesora w dziedzinie kształcenia dorosłych, będący swoistą notą przewodnią wprowadzającą uczestników w prezentowane obszary. Problematyka wystąpień podczas konferencji podzielona została na następujące sesje tematyczne: jakość, umiejętność czytania i pisania, wyższe wykształcenie, korzyści z nauki, życie zawodowe, nauka wychowawców, wspólnotowa edukacja, historia, rodzice i nieformalna edukacja, e-learning, finansowanie, rozpoznawanie i testowanie, teoria, edukacja międzykulturowa, młodzi dorośli i szkoły dla osób dorosłych, ruchy społeczne i wspólnotowa edukacja, uczenie się międzygeneracyjne i historia życia, historia ESREA, wychowawca, transformatywna nauka, miejsca edukacji dorosłych.

Materiały z konferencji są dostępne w wersji elektronicznej na stronie: http://edoc.hu-berlin.de/oa/books/rejEAjEFWlyvs/PDF/21lTOJmgrcsMM. pdf oraz jako książka pod red. Bernda Käpplingera i Steeffi Robak, Changing Congurations in Adult Education in Transitional Times. International Perspectives in Different Countries, Studies in Pedagogy, Andragogy, and Gerontagogy. Vol. 62, Peter Lang Verlag: Frankfurt a/M. 2014. 